\title{
Establishment of ventral cell fates in the Drosophila embryonic ectoderm requires DER, the EGF receptor homolog
}

\author{
Erez Raz and Ben-Zion Shilo ${ }^{1}$ \\ Department of Molecular Genetics and Virology, Weizmann Institute of Science, Rehovot 76100, Israel
}

\begin{abstract}
The embryonic ectoderm in Drosophila displays a highly organized arrangement of specific structures along the dorsal-ventral axis. To establish this characteristic design, cells must receive instructive cues regarding their position. We present evidence that during stages 8-9 of embryonic development, the Drosophila EGF receptor homolog (DER) is essential for determining the identity of cells within the ventral ectoderm. In the absence of DER activity at this phase, alterations in cell fate are observed: Ventral cells acquire more dorsal fates, as visualized by the expression profile of specific markers. The ventralizing effect of DER appears to function later than that of the dorsalizing $d p p$ pathway, and the spatial overlap between them is minimal. A model for the determination of cell fates along the dorsal-ventral axis involving the two pathways is presented. Some aspects of the mutant ectodermal and CNS phenotypes of the DER locus (faint little ball, flb) resemble the phenotype of mutations from the spitz group. Synergistic interactions between $f l b$ and spitz or Star mutations suggest that these genes participate in a common signaling pathway.
\end{abstract}

[Key Words: Drosophila, DER; embryonic development; dorsal-ventral polarity; receptor tyrosine kinase; $\mathrm{EGF}, d p p]$

Received April 23, 1993; revised version accepted August 9, 1993.

The initial dorsal-ventral pattern of the Drosophila embryo is determined by a group of maternal genes whose activity culminates in a ventrally biased gradient of nuclear localization of the dorsal protein (for review, see Anderson 1987; Roth et al. 1989; Rushlow et al. 1989; Steward 1989). Because dorsal is a transcription factor of the NF- $\mathrm{kB}$ family, its gradient of nuclear localization gives rise to an asymmetric pattern of transcription of zygotic genes, subdividing the embryo into three principal domains (Roth et al. 1989, 1991). The ventral domain in which dorsal is most active displays twist (twi) and snail (sna) transcription and develops as mesoderm following cellularization (Thisse et al. 1987, 1991; Leptin and Grunewald 1990; Jiang et al. 1991; Leptin 1991; Pan et al. 1991). The dorsal domain, in which dorsal protein is excluded from the nuclei, exhibits transcription of $z y-$ gotic genes such as decapentaplegic $(d p p)$ and tolloid $|t l d|$, which are crucial for development of dorsal structures (Roth et al. 1989; Ray et al. 1991). Finally, the intermediate region bracketed by the mesodermal and dorsal domains gives rise to the ventral neuroectoderm following gastrulation and is specifically marked by expression of early zygotic genes such as rhomboid (rho) (Ip et al. 1992).

Although the dorsal nuclear gradient generates a

${ }^{1}$ Corresponding author. coarse definition of three domains, the final dorsal-ventral patterning of the embryo must result from a zygotic refinement of these initial coordinates (Ray et al. 1991). Thus, understanding the mechanisms governing development along the dorsal-ventral axis requires the identification of relevant zygotic genes and the interactions between their products that may establish the full repertoire of cell fates, based on the maternally defined pattern. The dpp protein, a TGF- $\beta$ homolog (Padgett et al. 1987), has been shown to be the cardinal morphogen determining graded cell fates along the dorsal region. Although $d p p$ is transcribed uniformly in the dorsal domain (St. Johnston and Gelbart 1987), post-translational modifications and diffusion of the secreted protein may generate a graded distribution of the active form of dpp. Indeed, injection of increasing amounts of $d p p$ RNA into embryos resulted in progressive alterations toward more dorsal cell fates (Ferguson and Anderson 1992a).

Less is known about determination of polarity within the ventrolateral domain of the blastoderm embryo. This region of the ectoderm gives rise to two distinct structures: the central nervous system (CNS) and the ventral epidermis (Campos-Ortega and Hartenstein 1985). Mutations affecting these structures should help to identify zygotic genes that control differentiation of this domain. One set of loci functioning in the ventral ectoderm has been collectively termed the spitz group (Mayer and Nüsslein-Volhard 1988). Mutations in genes from this 
class cause similar pattern abnormalities in both the ventral epidermis and the CNS: In all spitz group mutants the size of the ventral epidermis is reduced, and a characteristic CNS phenotype is observed (Mayer and Nüsslein-Volhard 1988). A more dramatic disruption of the ventral derivatives was found in mutations of the faint little ball ( $f l b)$ locus, which encodes the Drosophila epidermal growth factor (EGF) receptor homolog (DER) (Nüsslein-Volhard et al. 1984; Price et al. 1989; Schejter and Shilo 1989; Clifford and Schüpbach 1990; for review, see Shilo and Raz 1991). Severe flb mutant embryos exhibit a complete loss of ventral structures, no secretion of denticle bands, and a severe CNS phenotype characterized by a collapse of horizontal commissures and discontinuities along the longitudinal axon tracts.

In view of the cardinal role of DER in development of the ventral ectoderm, it was important to determine its role during different stages of embryonic development. To this end, the embryonic $f l b$ phenotype has been dissected in time using a temperature-sensitive allele. DER was found to be required for ectoderm development at several distinct phases (Clifford and Schüpbach 1992; Raz and Shilo 1992). Elimination of DER activity at stages $8-9$ resulted in germ-band retraction defects, and a severe CNS phenotype. Because DER is expressed at this phase in the ectoderm and in the mesoderm, but not in neuronal cells, it has been postulated that the flb CNS phenotype results from defects in the ventral ectoderm where the cells of the nervous system originate. Later, during stages 11-12 of embryonic development, DER was shown to be crucial for differentiation of the ventral epidermis. In the absence of DER activity at this stage, the embryonic cuticle is completely devoid of ventral denticle bands. Finally, loss of DER activity at stage 13 results in lack of the midline glial (MG) cells.

To better define the early role of DER in the ventral ectoderm, we examined the development of this domain in mutant $\mathrm{flb}$ embryos using a variety of molecular markers. We show that DER is essential for generation of ventral cell fates during stages 8-9 and that more dorsal fates invade the ventral region if these fates are not properly established. Genetic evidence for the participation of genes from the spitz group in the same pathway as DER during ventral ectoderm development is also presented.

\section{Results \\ Ectoderm development in $\mathrm{flb}$ embryos}

The various $f l b$ mutations can be arranged in a phenotypic series in which progressive loss of ventral cuticle is observed. The cuticle secreted by null $f l b$ embryos is composed almost exclusively of dorsal structures (Fig. 1D), whereas the cuticles of weaker flb alleles exhibit differentiation of ventral structures (Fig. 1B,C,F). The cuticle phenotype reflects the condition of the embryo at the end of embryogenesis. It represents the composite

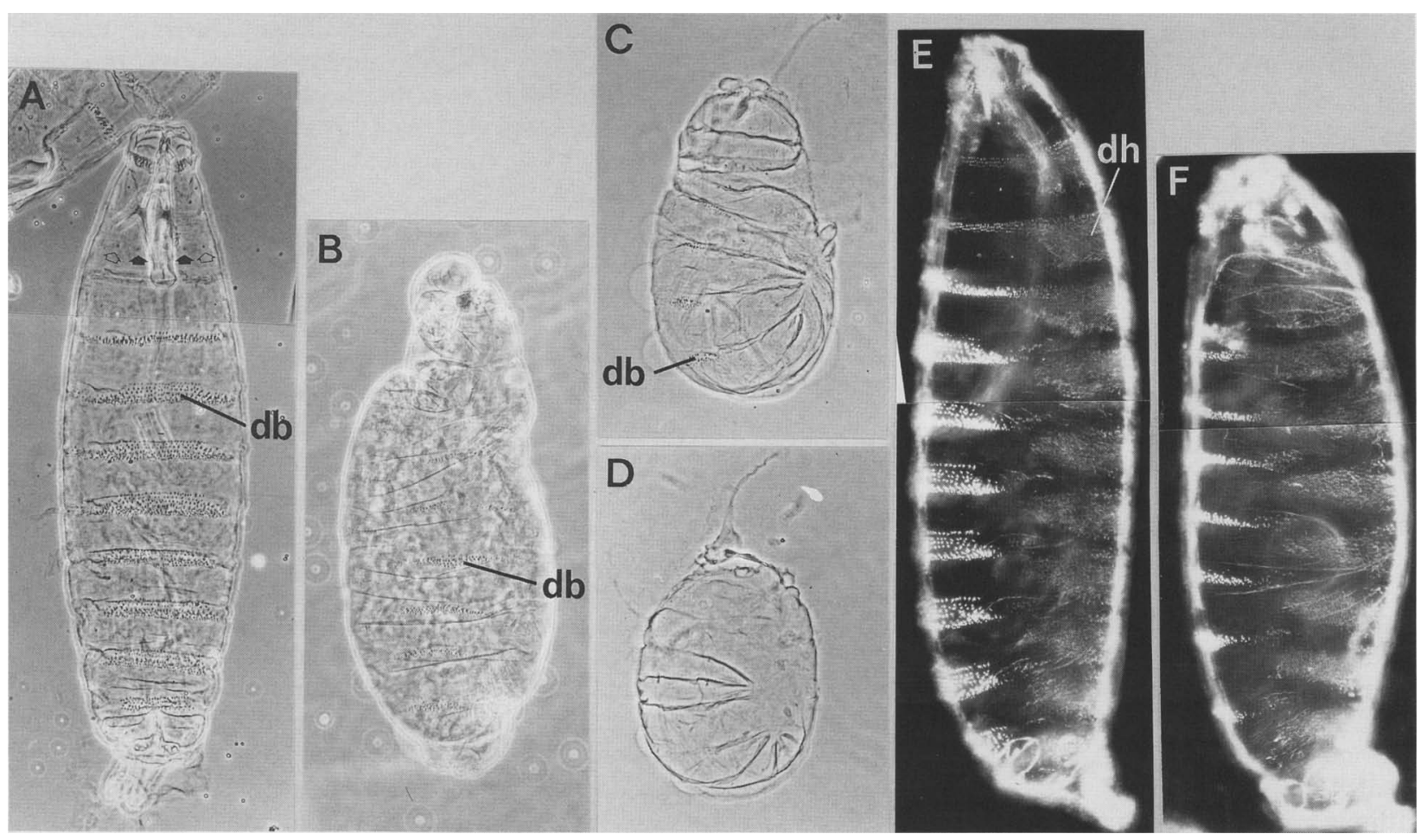

Figure 1. Cuticle phenotypes of $f l b$ embryos. $(A)$ Wild-type embryo, ventral view. $(B)$ Weak $f l b$ embryo $\left(f l b^{2 E O 7}\right) \cdot(C)$ Intermediate $f l b$ embryo $\left(f l b^{2 C 82}\right)$. (D) Severe $f l b$ embryo $\left(f l b^{2 L 65}\right)$. (E) Wild-type embryo, side view. $(F) f l b^{2 E O 7}$, side view. Solid arrows show Keilin's organs; open arrows show the ventral black dots. (db) Denticle bands; (dh) dorsal hairs. 
effect resulting from absence of DER throughout embryonic development, thus making detailed analysis of the phenotype difficult.

The complex cuticle defects can be dissociated into two discrete phases by temperature shifts of the temperature-sensitive allele $f 1 b^{1 F 26}$. $f l b^{1 F 26}$ mutants die as embryos with very minor cuticular defects when grown at the permissive temperature $\left(18^{\circ} \mathrm{C}\right)$ and show a severe $f 1 b$ phenotype at the restrictive temperature $\left(29^{\circ} \mathrm{C}\right)$ comparable to that of embryos homozygous to a deficiency of the $11 b$ region (Raz et al. 1991; Clifford and Schüpbach 1992; Raz and Shilo 1992). Cuticles of homozygous $\mathrm{flb}^{1 F 26}$ embryos that were maintained at the restrictive temperature until $5 \mathrm{hr}$ after egg lay (AEL) (stage 10) and subsequently shifted to the permissive temperature show defective germ-band retraction and defective dorsal-ventral patterning (Fig. 2A). Keilin's organs are displaced ventrally and show only $25 \%$ of the normal spacing between them. Similarly, the size of the denticle bands is reduced. Nevertheless, the capacity of the re-
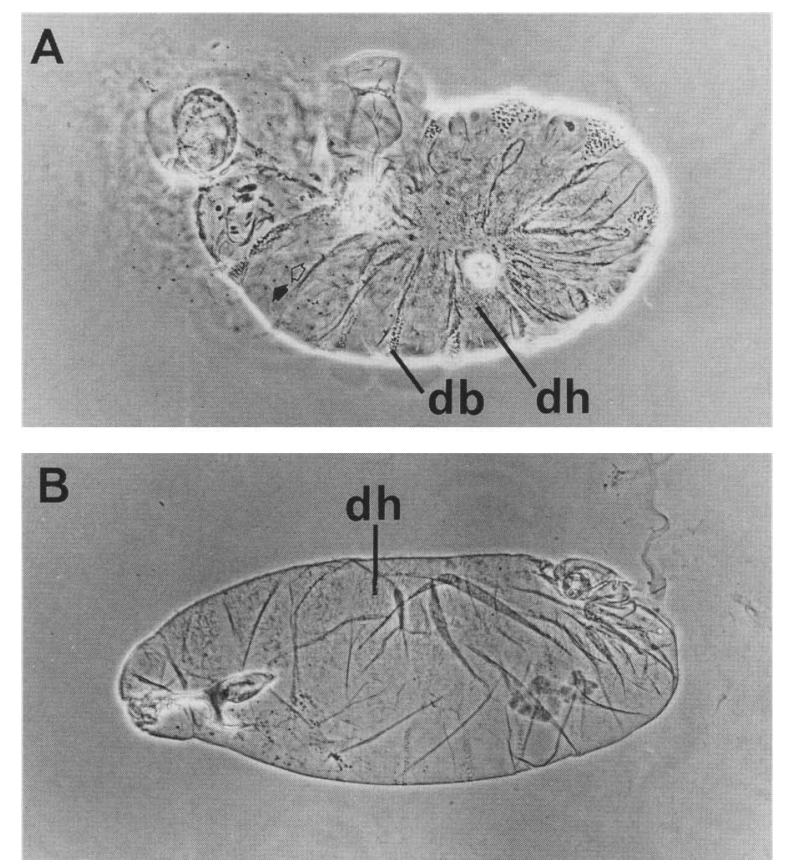

Figure 2. Two temporally distinct roles for DER in patterning the embryonic ectoderm. Shifting homozygous $f 1 b^{1 F 26}$ embryos between the restrictive temperature $\left(29^{\circ} \mathrm{C}\right)$ and the permissive temperature $\left(18^{\circ} \mathrm{C}\right)$ allowed the definition of two phases of DER function. $(A)$ Cuticles of embryos grown at the restrictive temperature for the first $5 \mathrm{hr}$ of development and then shifted to the permissive temperature show germ-band retraction defects and reduction in the size of the ventral ectoderm as visualized by the reduced spacing between the Keilin's organs. $(B)$ Conversely, embryos grown at the permissive temperature for the first $5 \mathrm{hr}$ of development and then shifted to the restrictive temperature undergo germ-band retraction but show almost no differentiation of the ventral ectoderm. The solid arrow shows Keilin's organs; the open arrow shows the ventral black dot. (db) Denticle bands; (dh) dorsal hairs. duced ventral epidermis to differentiate is retained, as denticle bands are observed in all segments. In contrast, embryos that were shifted to the restrictive temperature at $5 \mathrm{hr}$ AEL undergo germ-band retraction and display the normal pattern of dorsal hairs on every segment but show almost no differentiation of ventral structures (Fig. 2B).

This work will concentrate on the role of DER in patterning the ectoderm during stages 8-9 of embryonic development. This function can be specifically studied by shifting embryos from the restrictive to the permissive temperature after $5 \mathrm{hr}$ of development, thereby eliminating the defects associated with later roles of DER.

\section{Cell fate changes in flb embryos}

The reduced spacing between ventrolateral structures in the cuticle of $f l b$ embryos prompted us to follow early markers for ectodermal cell fates within the ventral ectoderm, to determine the basis for these defects. An enhancer trap element integrated in the region of the disconnected (disco) gene (Cohen et al. 1991) was used. Starting at stage 11, this enhancer trap marks the two ventrolateral cell clusters (which are the precursors for Keilin's organs/ within each of the three thoracic segments and smaller clusters of cells in all abdominal segments. Each cluster labeled by the enhancer trap is normally separated from the midline by several cells (Fig. $3 \mathrm{~A})$. The position of these structures was monitored in homozygous $f l b^{1 F 26}$ embryos that were maintained at the restrictive temperature until $5 \mathrm{hr}$ AEL and then shifted to the permissive temperature. It can be clearly observed that an increased number of cells expresses the marker, resulting in enlarged clusters that appear fused (Fig. 3B). A similar result was obtained when embryos homozygous for the chromosomal deficiency (2R)PK1, which removes the DER locus, were stained with a probe for the Distalless (DII) gene, marking Keilin's organs precursors (not shown). Interestingly, an intermediate phenotype can be observed in homozygous $f 1 b^{1 F^{26}}$ embryos grown at $18^{\circ} \mathrm{C}$. Although these embryos do not show fusion of the Keilin's organs, some of their ventral cells, which normally do not express the disco enhancer trap, appear to show weak levels of expression (Fig. 3C). These observations suggest that the early $f l b$ phenotype results from cell fate changes, where ventral cells express lateral markers.

To further establish the fact that in $f l b$ embryos the ventral-most cells assume lateral fates, we monitored simultaneously the expression of ventral and lateral markers. Ventral ectodermal fates were followed by fasciclin (fas) III staining, showing in wild-type embryos a patch of $\sim 20$ cells within each segment (Fig. 4A; Patel et al. 1987). Ventrolateral fates were monitored by staining Keilin's organs precursors $(\sim 20$ cells on each side), or the tracheal pits (Fig. 4A,C). In homozygous $f 1 b^{1 F 26}$ embryos that were maintained at the restrictive temperature during the first $5 \mathrm{hr}$ of development, no fas III-expressing cells are detected. Instead, the fates of these cells are replaced by Keilin's organs and the tracheal pits, which 
Figure 3. A shift in the fate of ventral ectodermal cells in $f l b$ embryos. The position of the cells that will give rise to Keilin's organs in the three thoracic segments was monitored by anti- $\beta$-gal staining of an enhancer trap line (C50.1S1), in which the element has integrated in the region of the disco gene. Staining was done at late stage 11 (6.5-7 hr AEL). (A) In wild-type embryos, the two clusters within each segment are separated. $(B)$ In homozygous $f 1 b^{1 F 26} \mathrm{em}$ bryos grown at $29^{\circ} \mathrm{C}$ for the first $5 \mathrm{hr} \mathrm{AEL}$, the two clusters are fused. (C) In homozygous $f 1 b^{1 F 26}$ embryos grown continuously at $18^{\circ} \mathrm{C}$, the spacing between the two clusters is comparable with wild-type embryos, yet some ventral cells that normally do not express this marker show weak $\beta$-gal expression (marked by the arrow). The embryos are shown from a ventral view; anterior is at the top.

extend ventrally (Fig. 4B,D). The salivary gland placodes can be visualized by fork head (fkh) RNA staining. Their ventral border lies about one cell ventral to that of the Keilin's organs (i.e., three to four cells from the midline) (Panzer et al. 1992). Like the Keilin's organs, the salivary glands lose the characteristic spacing in $f l b$ embryos and, instead, are fused along the midline (not shown). orthodenticle (otd) transcription pattern provides another marker to follow the fate of the ventral ectodermal cells. otd is normally expressed in a stripe three to four cells wide on either side of the ventral midline in the extended germ-band stage (Wieschaus et al. 1992). In flb embryos, otd staining in these cells is lost (not shown). Similarly, in embryos homozygous for the (2R)PK1 deficiency, both fas III and otd staining in the ventral ectoderm is absent.

A gradation of cell fates can be identified within the ventral region that is influenced by DER. In wild-type embryos, the ventral-most cells in the tracheal pits are separated from the midline by seven to eight cells (Fig. $4 \mathrm{D})$. The ventral border of Keilin's organs is five cells from the midline (Figs. 4A,B and $5 \mathrm{~A}$ ), and the salivary gland placodes are separated from the midline by only three to four cells (Panzer et al. 1992). These different identities all lie within the region that is affected by the DER pathway, because in $f l b$ embryos all three markers are expressed by the cells immediately adjacent to the midline (Figs. 4B,D; data not shown).

Extensive cell death is a distinct feature of $f l b$ embryos (Clifford and Schüpbach 1992; Raz and Shilo 1992). Cell death, however, does not appear to be involved in the early alteration in the position of structures within the ventral ectoderm, described above. Cell death results primarily from eliminating DER activity at 6-8 hr AEL, in the second phase of DER function in the ectoderm (Raz and Shilo 1992). The shift in the position of Keilin's organs is observed as early as early stage 11 , before extensive cell death begins. This issue was examined directly in sections of $f l b^{1 F 26}$ embryos carrying the disco enhancer trap, which were shifted to the permissive temperature at $5 \mathrm{hr}$. Whereas in wild-type embryos at stage
11 each one of Keilin's organs precursors is separated from the midline by about five cells (Fig. 5A), in $f l b \mathrm{em}$ bryos the Keilin's organs precursors are fused, without any indication for darkly stained dead cells (Fig. 5B). The cell clusters in the mutant embryos appear more elongated and a larger number of cells in the ventral region has taken the fate of Keilin's organs precursors. The dorsal border of Keilin's organs does not appear to be affected, however, in the mutant embryo, and the defect is restricted to the expansion of the ventral border of Keilin's organs.

\section{$D E R$ controls late dpp expression pattern in the ventral ectoderm}

It has been suggested that the information required for proper positioning of Keilin's organs precursors along the anterior-posterior and the dorsal-ventral axes is provided by the wingless $(\mathrm{wg})$ and the dpp proteins, respectively (Cohen 1990; Cohen et al. 1993). At 5-5.5 hr of development the $w g$ and $d p p$ genes generate a ladder-like structure composed of the ventromedial $w g$ stripes interconnected by the longitudinal $d p p$ stripes (Fig. 6A; Cohen et al. 1993). This late expression pattern of $d p p$ is distinct from the early pregastrulation dorsal expression pattern, which is not altered in $f 1 b$ embryos (Clifford and Schüpbach 1992). Cohen et al. (1993) suggested that cells positioned at the region of intersection between the wg and the $d p p$ stripes are provided with both secreted signaling molecules and subsequently express Keilin's organs markers (Fig. 6A,D). In support of this notion, both $w g$ and $d p p$ mutant embryos fail to express the characteristic molecular markers of the Keilin's organs /Cohen 1990; Cohen et al. 1993).

As shown above, in the absence of DER activity the ventral border of the Keilin's organs precursors shifts ventrally, whereas the dorsal border is not altered. To determine whether this phenotype is caused by alteration in the expression profile of the wg or $d p p$ genes, we monitored their expression patterns in flb embryos. Although the wg expression domain is not affected in the 

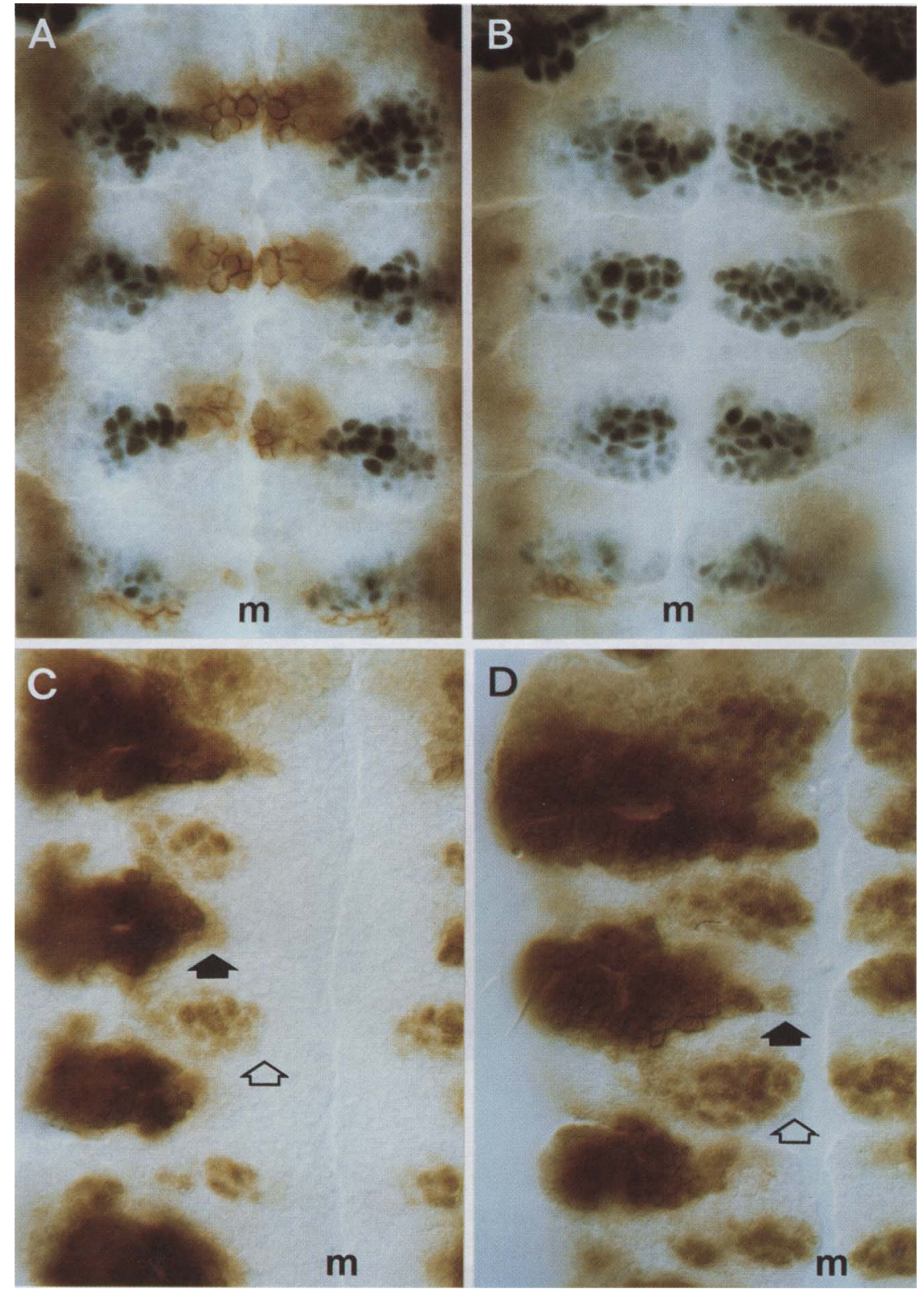

Figure 4. Substitution of ventral fates with more lateral fates in the ventral ectoderm of $f l b$ embryos. Three markers were followed in wild-type $(A, C)$ and homozygous $f 1 b^{1 F 26}$ embryos grown at $29^{\circ} \mathrm{C}$ during the first $5 \mathrm{hr}$ of development $(B, D)$. The disco enhancer trap labels Keilin's organs precursors (blue staining in $A$ and $B$; brown staining in $C$ and $D \mid$. fas III marks the ventral-most cells (brown staining in $A)$, and the 1-eve-1 enhancer trap denotes the tracheal pits $(C, D)$. Flat preparations of stained embryos were photographed. Whereas in the wild-type embryo, Keilin's organs are separated by fas III-expressing cells $|A|$, in $f l b$ embryos the ventral-most cells express the disco marker and do not show expression of fas III $(B)$. The expansion of lateral fates into the ventral region is also observed when the tracheal pit cells are marked $(C, D)$. The ventral borders of Keilin's organs and the tracheal pits show a gradation of cell fates. In the wild-type embryo $(C)$, the ventral border of the Keilin's organs precursors (open arrow) is two to three cells closer to the midline than the ventral border of the tracheal pits (solid arrow). (Note: the first tracheal pit is an exception; it is larger than the other pits and extends ventrally as far as Keilin organs). In mutant $f l b^{1 F 26}$ embryos grown at $29^{\circ} \mathrm{C}$ during the first $5 \mathrm{hr}$ of development, the disco and 1-eve-1 expression expands ventrally as far as the midline $(D)$, indicating that both are normally found in the domain influenced by the DER pathway. $(\mathrm{m})$ Ventral midline. mutant (not shown), a dramatic change in expression pattern of the $d p p$ gene is observed; in $f l b$ embryos the stripe of cells expressing $d p p$ is significantly wider than in wild-type embryos (up to 10 cells wide in $f l b$, vs. 4-6 cells in wild-type embryos; Fig. 6, cf. B and C with A). In the mutant embryos the dorsal border of the $d p p$ stripe is not altered, but the ventral border is shifted ventrally. It is interesting to note that the widening of the $d p p$ stripe is not uniform, where expression adjacent to the midline is seen only in cells outside the $w g$ expression domain (Fig. 6C). A wave-like $d p p$ expression is also observed in wild-type embryos, although it is less pronounced (Fig. 6A). This may indicate a segmentally repeated control mechanism inhibiting the ventral expansion of $d p p$ expression.
In conclusion, in the absence of DER activity, the $d p p$ gene is expressed in more ventral cells. Under these conditions, cells that normally receive only the secreted wg signal are also exposed to the secreted dpp signal and develop as Keilin's organs precursors (shown schematically in Fig. 6D,E).

\section{Temporal requirement for DER in ventral ectoderm patterning}

A shift in the fate of Keilin's organs precursors can be visualized as early as the onset of the disco enhancer trap expression, at $\sim 6 \mathrm{hr}$ AEL. Therefore, DER activity is clearly required before $6 \mathrm{hr}$ for proper patterning of the ventral domain. By applying temperature-shift protocols 


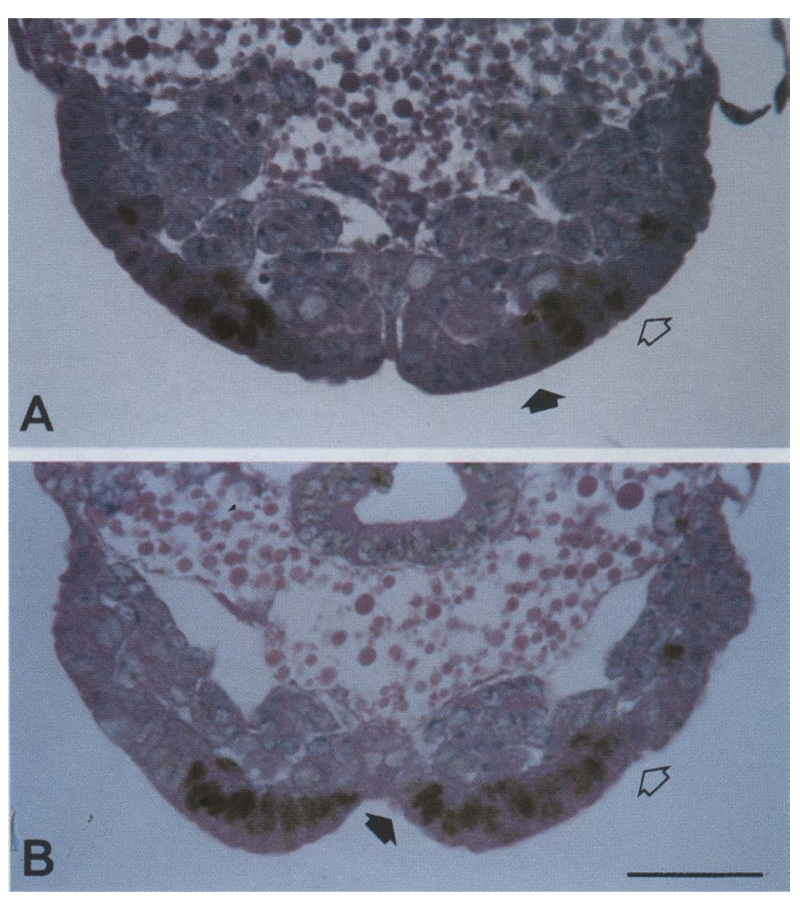

Figure 5. Sections showing cell fate changes in the ventral ectoderm of $f l b$ embryos. Embryos carrying the disco enhancer trap were stained with anti $\beta$-gal antibodies (brown) and sectioned. $(A)$ Cross section of late stage 11 wild-type embryo; $(B)$ $f l b^{1 F 26}$ embryo grown at $29^{\circ} \mathrm{C}$, shifted to $18^{\circ} \mathrm{C}$ at stage 10 , and fixed at late stage 11. In the wild-type embryo in this section only four cells express $\beta$-gal. They are separated from the midline by five cells. In contrast, in the flb embryo, the ventral cells that normally separate between Keilin's organs assume the more lateral fate and express the disco marker. About 10 cells on each side are stained in the mutant. Note that the dorsal borders of Keilin's organs are similar in the two embryos. This can also be inferred from the position of a dorsolateral dot of staining labeled by this enhancer trap. The dorsal and the ventral borders of the Keilin's organs are marked with open and solid arrows, respectively. Bar, $20 \mu \mathrm{m}$

to homozygous $f 1 b^{1 F 26}$ embryos carrying the disco enhancer trap, it was possible to determine the temperature-sensitive period for the activity of DER (Fig. 7). The results demonstrate that embryos grown at the permissive temperature between 3 and $4.5 \mathrm{hr}$ AEL show near normal spacing, whereas the fusion of Keilin's organs precursors is observed in embryos grown at the restrictive temperature at these times. We therefore conclude that DER is required at 3-4.5 hr AEL (stages 8-9) for patterning the ventral ectoderm. This time point precedes the 5- to $5.5-\mathrm{hr}$ period in which the intersecting expression of $w g$ and $d p p$ was shown to determine the position of the Keilin's organs precursors (Cohen et al. 1993).

\section{Relationships between $D E R$ and genes from the spitz group}

Although the combination of the severe defects found in null $f l b$ embryos is unique for this mutation, the ability to dissect the complex flb phenotype has allowed us to look for other mutations that share similar features. The phenotypes observed in members of the spitz group resemble the $f l b$ defects in several respects. A mild shift in the fates of ventral ectodermal cells was also observed for members of the spitz group, including most notably, spitz (spi), Star (S), and rho (Mayer and Nüsslein-Volhard 1988). In these mutants the spacing between ventrolateral structures, such as the ventral black dot and the Keilin's organs, is reduced. A shift of cell fates was also shown when the position of the salivary glands was monitored in spitz group mutants (Panzer et al. 1992). An additional phenotype shared by these three mutants is a frequent intersegmental fusion of denticle bands in the central portion of the segment, a phenotype that is also seen in some combinations of $f l b$ alleles (e.g., see Fig. 8B-D). Finally, the CNS phenotype of mutants in these genes was shown to result from specific defects in the three pairs of MG cells within each segment (Klämbt et al. 1991|. Similar defects in the MG cells were found in $f l b$ embryos in which the late functions of DER were specifically abolished (Raz and Shilo 1992). Taken together, it appears that the phenotypes of spi and $S \mathrm{mu}$ tants are milder than the null phenotype of $f l b$. It should be noted, however, that these genes may have a maternal contribution that could partially mask their early zygotic phenotypes (Mayer and Nüsslein-Volhard 1988; Rutledge et al. 1992), whereas DER has no maternal transcripts (Zak et al. 1990; Clifford and Schüpbach 1992).

These observations suggest that DER and the spitz group genes may participate in a common signaling pathway. To test this notion, double-mutant strains for $f l b$ and either spi or $S$ were constructed. We have chosen to use a trans-heterozygous combination of two severe $f l b$ alleles that complement each other to produce a weak phenotype (Fig. 8A,B; Raz et al. 1991). This genetic combination generates a sensitized condition where alterations in other elements of the DER signal transduction pathway can be more readily detected. The experiment tests the consequences of a complete lack of zygotic function and half of the maternal contribution of the spi or $S$ genes in a weak $f l b$ background.

We have chosen to examine the cuticle phenotype, which represents the cumulative defects resulting from the absence of all DER functions throughout embryogenesis and thus provides a sensitive assay for interaction. Double-mutant embryos for $f l b$ and spi or $S$ show a synergistic phenotype (Fig. 8E,F). Moreover, the phenotype suggests that the spi and $S$ gene products may participate in the DER signal transduction pathway in multiple stages of embryonic development. For example, the process of germ-band retraction for which DER is required during stages 8-9 (Raz and Shilo 1992; Clifford and Schüpbach 1992) does not take place in the double mutants. Similarly, the CNS (not shown) and the head phenotype, determined at the same stage, are significantly more severe when the two mutations are combined. Similar interactions were observed at the cuticle level with other combinations of $f l b$ and spi or $S$ alleles. The weak $f l b$ phenotype $\left(f l b^{1 F 26} / f 1 b^{2 X 51}\right.$ grown at $\left.21^{\circ} \mathrm{C}\right)$ was 

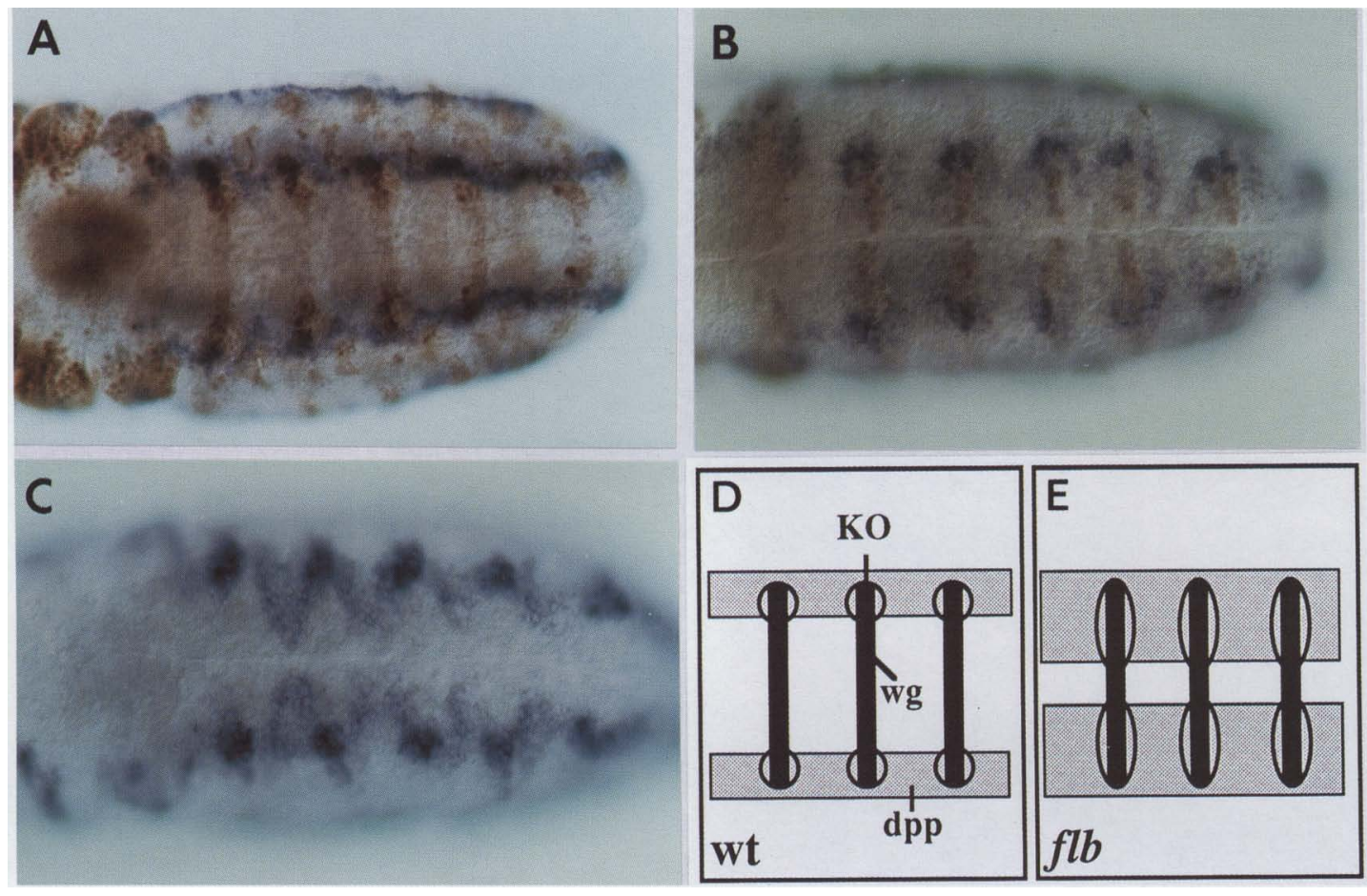

Figure 6. The effect of DER activity on the late expression pattern of the $d p p$ gene. Wild-type $(A)$ and homozygous $f 1 b^{1 F 26}(B, C)$ embryos carrying the disco enhancer trap were stained for the wg and $\beta$-gal proteins $[(A, B)$ brown non-nuclear and nuclear staining, respectively] and for $d p p$ RNA $[(A-C)$ blue staining]. The wild-type $d p p$ staining pattern, normally four to six cells wide $(A)$, is broader in the $f l b^{1 F 26}$ mutant grown at the restrictive temperature and includes up to 10 cells $(B, C)$. Broadening of Keilin's organs precursors in the mutant is also observed. wg staining can be seen in $A$ as a faint, non-nuclear brown staining between Keilin's organs. A scheme of the distribution of the secreted wg protein (solid vertical bars) and the predicted distribution of the secreted dpp protein (shaded horizontal bars) is shown for wild-type $(D)$ and mutant $f l b$ embryos $(E)$. The position of the Keilin's organs precursors (KO) is encircled.

enhanced dramatically by homozygosity for $s p i\left(s p i^{I-I A}\right.$ $\left.f 1 b^{1 F 26} / \mathrm{spi}^{T 25} \mathrm{flb^{2X51 }}\right)$ or $S\left(S^{I I N 23} \mathrm{flb^{1F26 } / S ^ { I N 2 3 }} f 1 b^{2 X 51}\right)$ (not shown). When checked with molecular markers, the $f 1 b^{2 \times 51} / f l l^{2 L 65}$ combination by itself showed considerable reduction of the ventral region. Thus, molecular markers for dorsal-ventral fates proved to be less useful than the cuticle phenotype in examination of interactions between $f l b$ and the spitz group genes.

The second phase in which DER allows proper differentiation of the ventral ectoderm also seems to require the function of spi and $S$. Relatively mild denticle band defects are observed in spi or $S$ embryos (Fig. $8 \mathrm{C}, \mathrm{D}$; Mayer and Nüsslein-Volhard 1988). In contrast, almost no denticle bands are detected in the double-mutant combinations with $f l b$ (Fig. 8E,F). In conclusion, lowering the levels of the spi and $S$ gene products in weak $f l b$ mutant embryos results in a cuticle phenotype resembling that of severe $f l b$ mutants. These genetic interactions suggests that spi and $S$ participate in a number of processes driven by the DER signaling pathway.

\section{Discussion}

\section{Determination of ventral cell fates}

On the basis of the maternal gradient of the dorsal protein, borders between three domains along the dorsal-

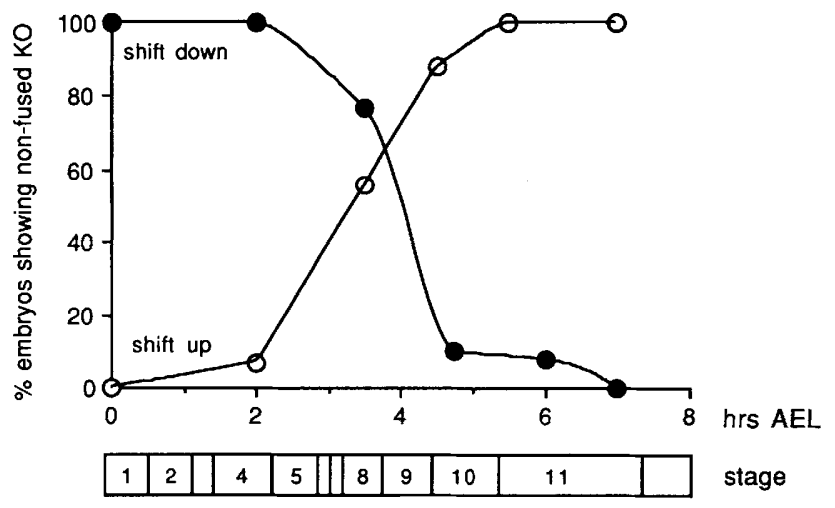

Figure 7. The temperature-sensitive period of $f 1 b^{1 F 26}$ for dorsal-ventral fate changes. The time axis is drawn according to the developmental stage at which the embryos were shifted (as determined for $25^{\circ} \mathrm{C}$ ). The percentage refers to embryos displaying the nearly wild-type spacing between Keilin's organs, similar to embryos continuously reared at $18^{\circ} \mathrm{C}$. (O) Shift-up results; $(0)$ shift down results. The embryonic stages are indicated below. Because of different developmental rates at different temperatures, the time axis is presented according to the developmental stage of the embryos at each point [in hours at $25^{\circ} \mathrm{C}$, in concordance with the stages of Campos-Ortega and Hartenstein (1985)], rather than by the chronological time that has elapsed. 

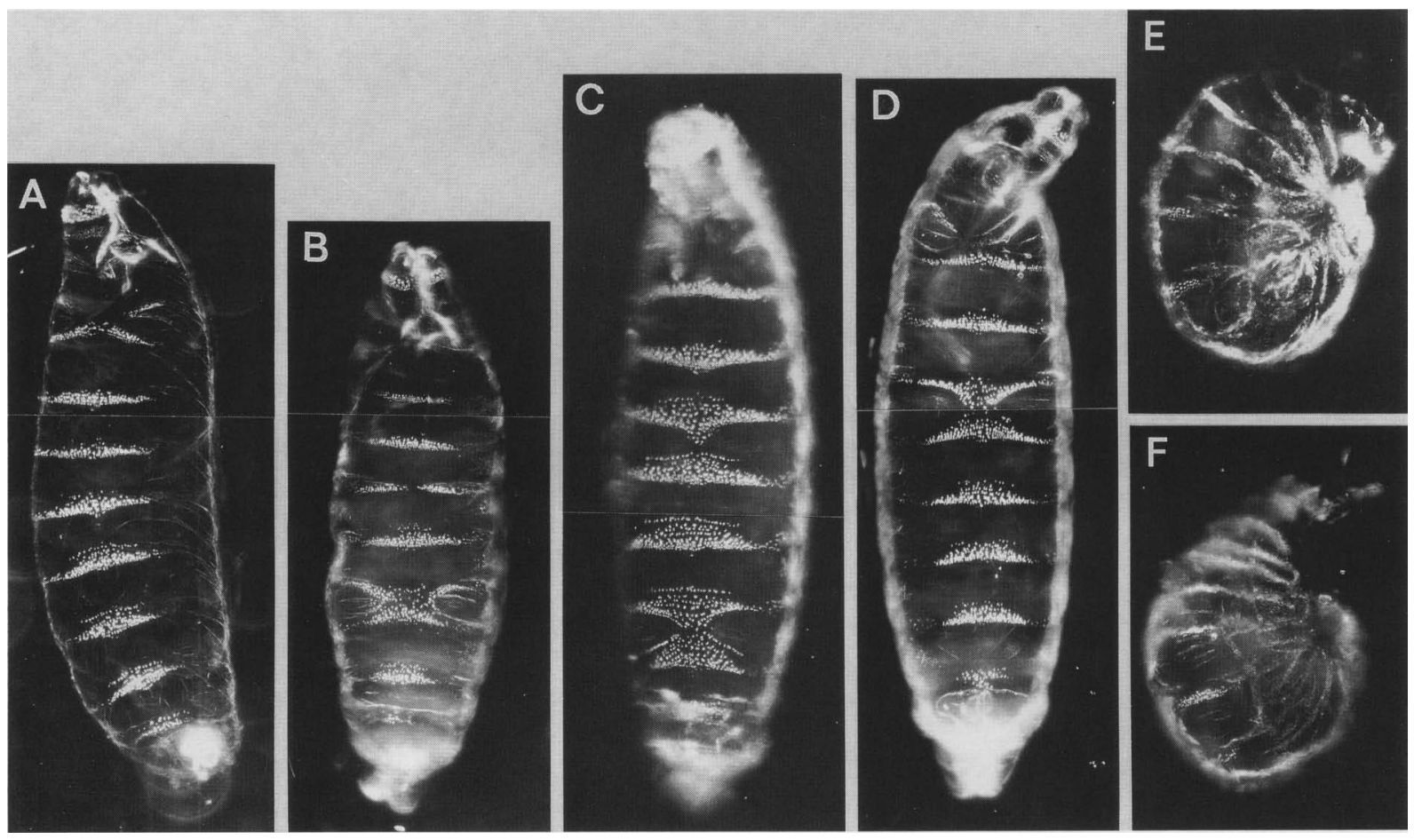

Figure 8. Synergistic interactions between $f l b$ and mutations of the spitz group. Cuticle preparations were done for embryos of the following genotypes: $(A, B) f l b$ mutants $\left(f 1 b^{2 L 65} / f 1 b^{2 X 51}\right)$. A shows a typical $f 1 b^{2 L 65} / f 1 b^{2 X 51}$ embryo with only a few ectopic denticles in the naked cuticle region of several segments. A small percentage of the embryos of this genotype $(<5 \%)$ exhibit a more severe phenotype $(B)$. In these embryos the denticle bands are smaller and show extensive fusion between segments. $(C)$ Homozygous spi

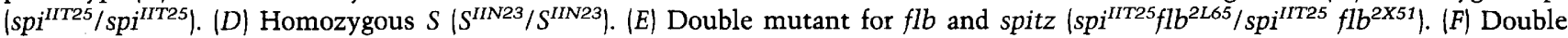
mutant for $f l b$ and $S\left(S^{I N 23} f 1 b^{2 L 65} / S^{I N 23} f 1 b^{2 X 51}\right)$. In the double mutants a synergistic interaction can be observed, resulting in a phenotype comparable to a severe $f l b$ embryo: The germ band fails to retract, head structures are missing, and the denticle bands are not formed.

ventral axis are established at the cellular blastoderm stage, before gastrulation. At this time point [stages $5-6$ $(2-3 \mathrm{hr}$ AEL $)]$, the zygotic dorsalizing pathway is recruited for determination and refinement of cell fates (Ferguson and Anderson 1992b). Examination of a phenotypic series of $d p p$ alleles and injection of $d p p$ RNA into embryos has demonstrated that a graded distribution of the active protein can give rise to a wide repertoire of cell fates (Ferguson and Anderson 1992a, b; Wharton et al. 1993). Is there a parallel zygotic pathway that is responsible for conferring ventral identity?

The necessity for an active mechanism to establish ventral polarity has been postulated from experiments eliminating both the maternal dorsal pathway as well as the zygotic $d p p$ pathway (Irish and Gelbart 1987). In these embryos, neither dorsal nor ventral structures are formed; instead, the embryos appear lateralized. Therefore, the establishment of dorsal fates, as well as the determination of ventral identities requires activation of specific pathways to overcome the default state of lateralization. This work has demonstrated a crucial role for DER in establishing ventral identity in the embryonic ectoderm. In the absence of DER activity at stages 8-9, lateral fates invade the ventral ectoderm: Keilin's organs precursors, the tracheal pits, and the salivary gland pla- codes, which are normally positioned ventrolaterally, occupy a more ventral part of the ectoderm. The shift of ventrolateral markers is accompanied by loss of the ventral-most markers. These changes are likely to result from the widening of the lateral stripe of $d p p$ expression. The alterations in expression domains observed in $f l b$ embryos result strictly from cell fate changes and not from cell death. Cell death in the abnormal ventral region probably becomes an important factor at later stages and contributes to the final $\mathrm{flb}$ phenotype (Clifford and Schübach 1992).

The three structures that were followed as markers for cell fate in the ventral region are not completely overlapping with respect to the dorsal-ventral axis. Therefore, within the boundaries of the ventral domain that is induced by the DER pathway, a spectrum of cell fates can be identified. What determines the graded dorsalventral fates in this region? Can different levels of activity of the DER pathway induce a range of cell fates?

To address this question, the ventral region was examined in embryos possessing different levels of DER activity. It is possible to generate embryos that have half of the normal DER amount (heterozygous for a DER deficiency) or a quarter of the normal amount (heterozygous for an $f l b$ mutation in the kinase domain, where presum- 
ably only a quarter of the receptors form functional homodimers|. In both cases, these embryos are viable and display the normal position of Keilin's organs (not shown). Finally, embryos overexpressing the wild-type DER protein under the heat shock promoter regulation showed no aberrant phenotypes (R. Schweitzer and B. Shilo, unpubl.). Thus, under physiological conditions, variations in the level of the DER protein cannot generate a range of cell fates. A similar notion has been presented for another receptor tyrosine kinase, torso, which appears to function in syncytial blastoderm embryos above the threshold level (Sprenger and Nüsslein-Volhard 1992). More dramatic reductions in the activity of DER were observed in $f 1 b^{1 F 26}$ mutant embryos at $18^{\circ} \mathrm{C}$. Under these conditions the ventral domain expressed intermediate fates. Although Keilin's organs remained in their normal position, the ventral cells between them expressed low levels of the $\beta$-gal marker, suggesting that the DER pathway may have the capacity to induce intermediate ventral fates.

Possible sources for positional information in the ventral ectoderm are the protein products of the maternal dorsal and the zygotic twi genes. Within the neuroectoderm these two proteins are found in a gradient of nuclear localization (dorsal) or amount (twi). For both proteins, the gradient shows a decrease in dorsal versus ventral cells (Roth et al. 1989; Rushlow et al. 1989; Steward 1989; Leptin and Grunewald 1990). Two possibilities for interactions between the dorsal/twi and DER pathways may be envisaged. First, the gradients of dorsal and twi could function upstream to the DER pathway and regulate its level of activity. A uniform ectodermal distribution at the RNA and protein levels of both DER and its candidate ligand spi have been reported (Zak et al. 1990; Rutledge et al. 1992). Although the level of the DER protein itself may not be normally restricted, other limiting elements in the cascade could potentially give rise to a graded activation of the pathway, for example, differential processing of the ligand or a restricted distribution of some elements in the DER signaling pathway such as rho, influenced directly or indirectly by the dor$\mathrm{sal} / \mathrm{twi}$ distribution. Alternatively, the dorsal or twi gradients could instruct cells to assume a range of ventral fates before the activation of DER. In this case, a uniform DER activity could be required for maintaining the spectrum of preformed ventral cell fates. This suggestion is consistent with the fact that dorsal-ventral organization of early proneural clusters in the ectoderm is already apparent before the time of DER function (Cabrera et al. 1987). In $f l b$ embryos a seemingly normal pattern of these cells is observed (not shown). If a graded DER activity is not essential for its biological function, we would expect to be able to rescue the early flb defects by a constitutively active DER protein, or by activated downstream elements such as the Dras or Draf proteins.

How is the ventralizing activity of DER coordinated with the early dorsalizing pathway? DER activity is not required at the pregastrulation phase when $d p p$ function but, rather, at 3-4.5 hr AEL. The borders between the $t w i$ and $d p p$ domains within the cellular blastoderm embryo appear to be established correctly in $f l b$ embryos, and gastrulation seems normal (Clifford and Schüpbach 1992). Thus, there is a temporal difference between the initial establishment of the dorsal polarity by the $d p p$ pathway at 2-3 hr (Ferguson and Anderson 1992b) and determination of ventral identity by DER. It is conceivable that very little or no dpp protein reaches the ventralmost region. In $d p p$ null embryos, no extensive aberrations in the ventral-most region are seen, supporting the notion that $d p p$ does not influence these cells. For example, the median proneural clusters representing the most ventral domain are unaffected, whereas the lateral proneural clusters are extended dorsally in $d p p$ embryos (Skeath et al. 1992). Thus, the ventral ectodermal cells in wild-type embryos may remain undetermined when dorsal fates are established by early dpp function, or may be affected by an early dorsal/twi ventralizing pathway. Later on, at stages $8-9$, these cells are subjected to the DER-dependent activity. When the ventral cells do not receive a ventralizing signal from DER, as is the case in $f l b$ mutant embryos, the cells assume the default fate and display lateral markers. A model summarizing our current understanding of the cell fate determinations in the dorsal-ventral axis by the $d p p$ and DER pathways and the restricted spatial and temporal overlap between them is presented in Figure 9.

\section{Relationships between the spitz group genes and the DER signaling pathway}

Other mutations that give rise to a phenotype identical to that of $f l b$ embryos have not been identified. The ability to dissect this complex phenotype using the $f 1 b^{1 F 26}$ temperature-sensitive allele (Raz and Shilo 1992), however, allows the identification of known mutations that display a phenotype reminiscent of at least some aspects of $f l b$. Such mutations could provide potential candidates for elements in the signal transduction pathway of DER. The spitz group genes share several aspects of their mutant embryonic phenotype with $f l b$, including changes in ventral fates of ectodermal cells and defects in the MG cells (Mayer and Nüsslein-Volhard 1988; Klämbt et al. 1991).

Of the five zygotic loci originally defined in the spitz group, single-minded (sim) has been shown to function in the most ventral region of the embryo, namely the mesectoderm (Mayer and Nüsslein-Volhard 1988; Nambu et al. 1991). The other four genes [spi, S, rho, and pointed (pnt)] affect the ventrolateral domain in the fate map of the blastoderm embryo, (Mayer and NüssleinVolhard 1988; Klämbt 1993) and may participate in the differentiation of the ventral ectoderm.

To look for possible interactions between DER and spitz group genes, double-mutant combinations were examined. In the sensitized weak $f l b$ combination, homozygosity for spi or $S$ results in a synergistic phenotype reminiscent of severe $f l b$ defects. These interactions suggest that spi and $S$ have early roles in embryogenesis, which were not previously revealed by their mutant phenotype, possibly because of a maternal component that 
Figure 9. A model for the role of the DER pathway in establishment of dorsal-ventral polarity in the embryo. The basic concept of the model is the absence or temporal and spatial overlap between the dorsalizing $d p p$ pathway and the ventralizing DER pathway. Generation of a range of fates within each region may rely (directly or indirectly) on the gradient of nuclear localization of the maternal of the dorsal protein. At $3 \mathrm{hr}$ AEL, the dorsalizing activity of the $d p p$ pathway is executed in the dorsal region of the embryo (arrow), giving rise to the appearance of a range of dorsal cell fates (shaded cells). At $4 \mathrm{hr}$ AEL, the ventralizing activity of the DER pathway is manifested in the ventral region of the embryo (arrow). This region was not influenced previously by the $d p p$ pathway and displays several ventral cell fates (hatched cells). The lateral cells, which were not affected by either $d p p$ or DER pathways, assume the default fate (white cells). In $d p p$ mutant embryos, dor-

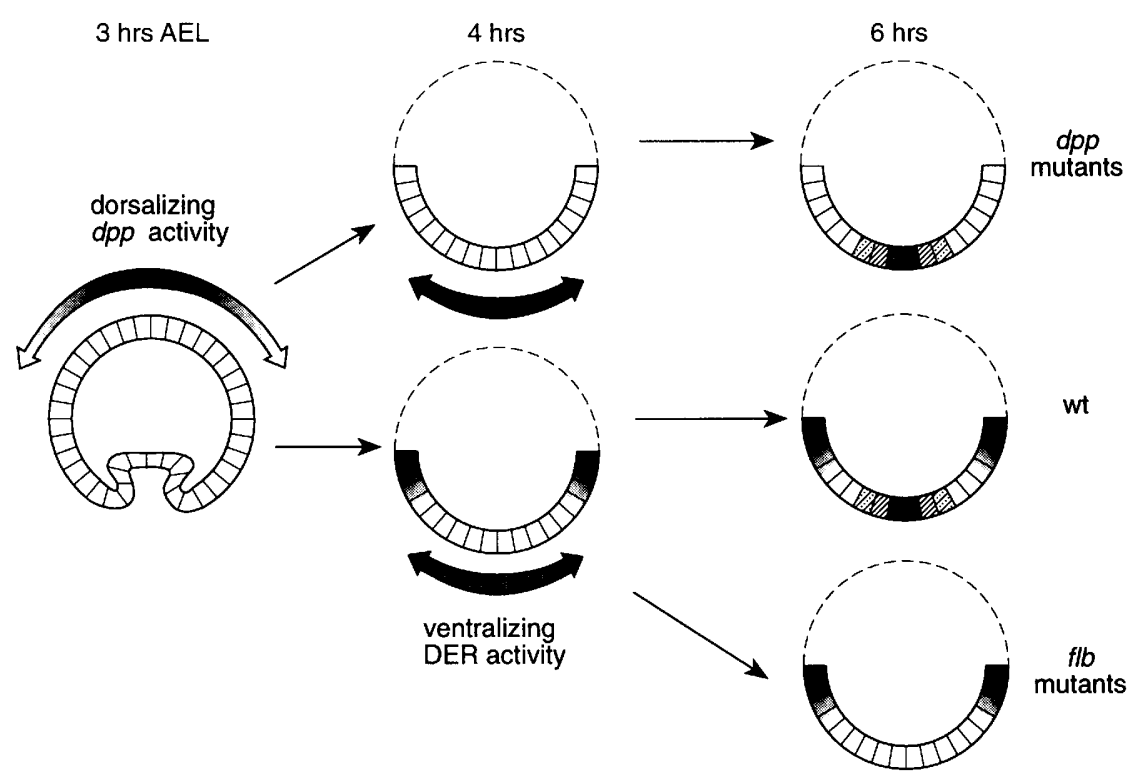
sal fates are not established, and lateral fates extend into the dorsal region. Polarity, however, is determined normally by the DER pathway within the ventral region. In $f l b$ mutant embryos dorsal polarity is established normally, but absence of the ventralizing activity causes expansion of lateral fates into the ventral region. Note: Only half-embryos are drawn for the 4- and 6-hr stages in which the embryos have an extended germ band.

masks their early zygotic requirement. spi encodes a protein homologous to TGF- $\alpha$ (Rutledge et al. 1992), one of the ligands triggering the vertebrate EGF receptor. The protein contains a signal peptide, a single EGF repeat followed by a putative dibasic cleavage signal, and a transmembrane and short cytoplasmic domain. This structure is certainly compatible with a direct interaction with DER, either as a cleaved peptide or in a membrane-bound form. The spi protein is capable of stimulating autophosphorylation of the DER protein expressed in Schneider S2 cells (R. Schweitzer and B. Shilo, unpubl.).

In contrast to spi and $S$, the rho and pointed (pnt) genes have no maternal component (Mayer and Nüsslein-Volhard 1988). Therefore, their phenotypes appear to reflect the null situation. If they are also part of the DER pathway, the weaker phenotype that they display compared with $f l b$, has to be accounted for by a different mechanism. One would have to postulate that they play a more restricted role than spi or $S$ in the DER signaling pathway, or that their functions are partially redundant. pnt encodes an ETS-like transcription factor (Klämbt 1993) and is thus not likely to be in direct physical interaction with the elements activating DER on the membrane. rho encodes a protein with multiple putative transmembrane domains (Bier et al. 1990) and may facilitate signaling through DER. Genetic interactions between the $f l b$ and $r$ ho genes have been demonstrated in the process of vein formation in the wing imaginal disc (Sturtevant et al. 1993). Restricted expression of rho in the dorsal follicle cells surrounding the oocyte appears to be crucial for localized activation of DER in the same cells (Ruohola-Baker et al. 1993). In the early embryo, rho is also expressed in a restricted pattern. In contrast to the broad expression of DER or spi, it is found only in the neuroectoderm (Bier et al. 1990; Ip et al. 1992). If rho plays a role in facilitating or enhancing the activation of DER, its restricted distribution may provide a basis for a higher level of DER activity in the neuroectoderm. Future work on the participation of the spitz group genes in the DER signaling pathway and their capacity to modulate its activity should provide further clues to the establishment of ventral polarity in the ectoderm.

\section{Materials and methods}

Drosophila strains

The following alleles were used: $f 1 b^{1 F 26}, f 1 b^{2 E O 7}, f l b^{2 C 82}, f 1 b^{2 X 51}$, $f l b^{2 L 65}, s^{I I N 23}, s p i^{I I T 25}$, and spi $i^{\text {IIA }}$. These strains were kindly provided by C. Nüsslein-Volhard, E. Wieschaus, and N. Perrimon (Nüsslein-Volhard et al. 1984; Rutledge et al. 1992). Df(2R)PK1 removing the DER locus (Schejter and Shilo 1989) was used to examine the $f l b$ null phenotype. To identify homozygous $f l b$ mutant embryos, a second chromosome balancer containing a $\mathrm{P}$ element with a $\mathrm{ftz}-\mathrm{lacZ}$ promotor fusion was used. The $\mathrm{CyO} \beta \mathrm{Cl}$ chromosome lobtained from Y. Hiromi, unpubl.), can be easily detected from stage 7 and onward by a characteristic striped staining pattern.

The C50.1S1 enhancer trap line was obtained from S. Cohen and W. Gehring (Cohen et al. 1991). The transposon has integrated in the region of the disco gene and displays an expression pattern similar to that of the disco gene. It was used in this work for labeling the precursors of Keilin's organs. The 1-eve-1 enhancer trap line used for labeling the tracheal pits was obtained from N. Perrimon (Perrimon et al. 1991).

\section{Embryo stainings and cuticle preparations}

To discriminate between wild-type and mutant embryos, bal- 
ancer chromosomes carrying $\mathrm{P}$ elements expressing $\mathrm{lac} Z$ were used. Expression of $l a c Z$ was detected either by staining the embryos with rabbit anti- $\beta$-gal antibodies (Cappel) or by standard X-gal staining. Antibody stainings and in situ hybridizations were done with minor modifications of previously described protocols (Ashburner 1989; Tautz and Pfeifle 1989). Anti-fkh antibodies were provided by Y. Kuo and S. Beckendorf (unpubl.), $f k h$ cDNA was obtained from $\mathrm{H}$. Jäckle (Weigel et al. 1989), DIl cDNA probe was obtained from Cohen (1990), otd cDNA was provided by R. Finkelstein (Finkelstein et al. 1990), and the $d p p$ probe from D. St. Johnston (St. Johnston and Gelbart 1987). Mouse antibodies against fas III were obtained from $T$. Volk (unpubl.). Rabbit antibodies against the wg protein were obtained from R. Nusse (van den Heuvel et al. 1988). For double-antibody labeling, embryos were incubated simultaneously with the two primary antibodies (mouse anti-fas III and rabbit anti- $\beta$-gal). After washing, the secondary horseradish peroxidase (HRP)-conjugated anti-rabbit antibody was added and washed, and the HRP reaction was done in the presence of $\mathrm{NiCl}_{2}$ and $\mathrm{CoCl}_{2}(3 \mu \mathrm{l}$ of $8 \%$ solution in a $300-\mu 1$ reaction mix) to produce the blue color. The embryos were then washed and incubated with the HRP-conjugated anti-mouse antibody, and the HRP reaction was done without $\mathrm{NiCl}_{2}$ and $\mathrm{CoCl}_{2}$ to produce the brown color in the reaction. When double labeling of the RNA and the protein was carried out, the antibody staining was followed by the RNA staining procedure.

Embryo sectioning of prestained embryos was done using the JB-4 resin according to a previously described protocol (Raz and Shilo 1992). The sections were then histologically stained with a basic fuchsin/methylene blue-based staining solution.

For cuticle preparations, embryo collections were allowed to develop until all wild type embryos hatched (36-48 hr AEL). The dead embryos were collected, dechorionated in bleach, washed in PBS, and devitelinized in heptane/methanol $(1: 1)$. The embryos were then washed in methanol, rehydrated in PBS and $0.1 \%$ Triton, and mounted in Hoyer's/lactic acid $(1: 1)$ (Wieschaus and Nüsslein-Volhard 1986). The embryos were allowed to clear for $12 \mathrm{hr}$ at $60^{\circ} \mathrm{C}$, and the cuticle phenotype was visualized with dark-field or phase microscopy.

\section{Temperature-shift protocols}

Temperature shifts of homozygous $f l b^{1 F 26}$ embryos were carried out as follows: One-hour egg lays were collected at $25^{\circ} \mathrm{C}$. Embryos were then allowed to develop at the restrictive $\left(29^{\circ} \mathrm{C}\right)$ or at the permissive $\left(18^{\circ} \mathrm{C}\right)$ temperature. The egg collections were shifted down or up, accordingly at the appropriate time points. The chronological time of the shifts shown in Figure 6 can be calculated as follows: For $18^{\circ} \mathrm{C}$ it is twice the time shown for $25^{\circ} \mathrm{C}$, and for $29^{\circ} \mathrm{C}$ it is 0.8 of the time shown.

\section{Acknowledgments}

We thank the following investigators for kindly providing strains or reagents used in this study: S. Beckendorf, S. Cohen, D. St. Johnston, W. Gehring, Y. Hiromi, P. Ingham, H. Jäckle, R. Nusse, C. Nüsslein-Volhard, N. Perrimon, and E. Wieschaus. In addition, we are grateful to all members of the Shilo laboratory for their support and helpful discussions, and to L. Glazer, $M$. Reichman-Fried, E. Schejter, and N. Zak for critical reading of the manuscript. This work was supported by grants from the National Institutes of Health, the Minerva Foundation, and the Forchheimer Center to B.S.

The publication costs of this article were defrayed in part by payment of page charges. This article must therefore be hereby marked "advertisement" in accordance with 18 USC section 1734 solely to indicate this fact.

\section{References}

Anderson, K.V. 1987. Dorsal-ventral embryonic pattern genes of Drosophila. Trends Genet. 3: 91-97.

Ashburner, M. 1989. Drosophila: A laboratory manual. Cold Spring Harbor Laboratory Press, Cold Spring Harbor, New York.

Bier, E., L.Y. Jan, and Y.N. Jan. 1990. rhomboid, a gene required for dorsoventral axis establishment and peripheral nervous system development in Drosophila melanogaster. Genes \& Dev. 4: 190-203.

Cabrera, C.V., A. Martinez-Arias, and M. Bate. 1987. The expression pattern of three members of the achaete-scute complex correlates with neuroblast segregation in Drosophila. Cell 50: 425-433.

Campos-Ortega, J.A. and V. Hartenstein. 1985. The embryonic development of Drosophila melanogaster. Springer-Verlag, Berlin/Heidelberg, Germany.

Clifford, R.J. and T. Schüpbach. 1990. Coordinately and differentially mutable activities of torpedo, the Drosophila melanogaster homolog of the vertebrate EGF receptor gene. Genetics 123: 771-787.

- 1992. The torpedo (DER) receptor tyrosine kinase is required at multiple times during Drosophila embryogenesis. Development 115: 853-872.

Cohen, B., E.A. Wimmer, and S.M. Cohen. 1991. Early development of leg and wing primordia in Drosophila embryo. Mech. Dev.. 33: 229-240.

Cohen, B., A.A. Simcox, and S.M. Cohen. 1993. Allocation of the thoracic imaginal primordia in the Drosophila embryo. Development 117: 597-608.

Cohen, S.M. 1990. Specification of limb development in the Drosophila embryo by positional cues from segmentation genes. Nature 343: 173-177.

Ferguson, E.L. and K.V. Anderson. 1992a. decapentaplegic acts as a morphogen to organize dorsal-ventral pattern in the Drosophila embryo. Cell 71: 451-461.

- 1992b. Localized enhancement and repression of the activity of the TGF- $\beta$ family member, decapentaplegic, is necessary for dorsal-ventral pattern formation in the Drosophila embryo. Development 114: 583-597.

Finkelstein R., D. Smouse, T.M. Capaci, A.C. Spradling, and N. Perrimon. 1990. The orthodenticle gene encodes a novel homeo domain protein involved in the development of the Drosophila nervous system and ocellar visual structures. Genes \& Dev. 4: 1516-1527.

Ip, Y.T., R.E. Park, D. Kosman, E. Bier, and M. Levine. 1992. The dorsal gradient morphogen regulates stripes of rhomboid expression in the presumptive neuroectoderm of the Drosophila embryo. Genes \& Dev. 6: 1728-1739.

Irish, V.F. and W.M. Gelbart. 1987. The decapentaplegic gene is required for dorsal-ventral patterning of the Drosophila embryo. Genes \& Dev. 1: 868-879.

Jiang, J., D. Kosmen, T. Ip, and M. Levine. 1991. The dorsal morphogen gradient regulates the mesoderm determinant twist in early Drosophila embryos. Genes \& Dev. 5: 18811891.

Klämbt, C. 1993. The Drosophila gene pointed encoded two ets like proteins which are involved in the development of the midline glia cells. Development 117: 163-176.

Klämbt, C., R. Jacobs, and C.S. Goodman. 1991. The midline of the Drosophila central nervous system: A model for the ge- 
netic analysis of cell fate, cell migration, and growth cone guidance. Cell 64: 801-815.

Leptin M. 1991. twist and snail as positive and negative regulators during Drosophila mesoderm development. Genes \& Dev. 5: 1568-1576.

Leptin, M. and B. Grunewald. 1990. Cell shape changes during gastrulation in Drosophila. Development 110: 73-84.

Mayer, U. and C. Nüsslein-Volhard. 1988. A group of genes required for pattern formation in the ventral ectoderm of the Drosophila embryo. Genes \& Dev. 2: 1496-1511.

Nambu, J.R., J.O. Lewis, K.A. Wharton, and S.F. Crews. 1991. The Drosophila single-minded gene encodes a helix-loophelix protein that acts as a master regulator of CNS midline development. Cell 67: 1157-1167.

Nüsslein-Volhard, C., E. Wieschaus, and H. Kluding. 1984. Mutations affecting the pattern of the larval cuticle in Drosophila melanogaster. I. Zygotic loci on the second chromosome. Wilhelm Roux's Arch. Dev. Biol. 193: 267-282.

Padgett, R.W., R.D. St. Johnston, and W.M Gelbart. 1987. A transcript from a Drosophila pattern gene predicts a protein homologous to the transforming growth factor- $\beta$ family. $\mathrm{Na}$ ture 325: 81-84.

Pan, D., J.-D. Huang, and A.J. Courey. 1991. Functional analysis of the Drosophila twist promotor reveals a dorsal-binding ventral activator domain. Genes \& Dev. 5: 1892-1901.

Panzer, S., D. Weigel, and S.K. Beckendorf. 1992. Organogenesis in Drosophila melanogaster: Embryonic salivary gland determination is controlled by homeotic and dorsoventral patterning genes. Development 114: 49-57.

Patel, N.H., P.M. Snow, and C.S. Goodman. 1987. Characterization and cloning of fasciclin III: A glycoprotein expressed on subset of neurons and axon pathways in Drosophila. Cell 56: 1085-1092.

Perrimon, N., E. Noll, K. McCall, and A. Brand. 1991. Generating lineage-specific markers to study Drosophila development. Dev. Genet. 12: 238-252.

Price, J.V., R.J. Clifford, and T. Schüpbach. 1989. The maternal ventralizing locus torpedo is allelic to faint little ball, an embryonic lethal, and encodes the Drosophila EGF receptor homolog. Cell 56: 1085-1092.

Ray, R.P., K. Arora, C. Nüsslein-Volhard, and W.M. Gelbart. 1991. The control of cell fate along the dorsal-ventral axis of the Drosophila embryo. Development 113: 35-54.

Raz, E. and B.-Z. Shilo. 1992. Dissection of the faint little ball $(f l b)$ phenotype: Determination of the development of the Drosophila central nervous system by early interactions in the ectoderm. Development 114: 113-123.

Raz, E., E.D. Schejter, and B.-Z. Shilo. 1991. Inter-allelic complementation among DER/flb alleles: Implications for the mechanism of signal transduction by receptor-tyrosine kinases. Genetics 129: 191-201.

Roth, S., D. Stein, and C. Nüsslein-Volhard. 1989. A gradient of nuclear localization of the dorsal protein determines dorsoventral pattern in the Drosophila embryo. Cell 59: 11891202.

Roth, S., Y. Hiromi, D. Godt, and C. Nüsslein-Volhard. 1991. cactus, a maternal gene required for proper formation of the dorsoventral morphogen gradient in Drosophila embryos. Development 112: 371-388.

Ruohola-Baker, H., E. Grell, T.-B. Chou, D. Baker, L.Y. Jan, and Y.N. Jan. 1993. Spatially localized Rhomboid is required for establishment of the dorsal-ventral axis in Drosophila oogenesis. Cell 73: 953-966.

Rushlow, C.A., K. Han, J.L. Manley, and M. Levine. 1989. The graded distribution of the dorsal morphogen is initiated by selective nuclear transport in Drosophila. Cell 59: 1165-
1177.

Rutledge, B.J., K. Zhang, E. Bier, Y.N. Jan, and N. Perrimon. 1992. The Drosophila spitz gene encodes a putative EGF-like growth factor involved in dorsal-ventral axis formation and neurogenesis. Genes \& Dev. 6: 1503-1517.

St. Johnston, R.D. and W.M. Gelbart. 1987. decapentaplegic transcripts are localized along the dorsal-ventral axis of the Drosophila embryo. EMBO I. 6: 2785-2791.

Schejter, E.D. and B.-Z. Shilo. 1989. The Drosophila EGF receptor homolog (DER) gene is allelic to faint little ball, a locus essential for embryonic development. Cell 56: 1093-1104.

Shilo, B.-Z. and E. Raz. 1991. Developmental control by the Drosophila EGF receptor homolog DER. Trends Genet. 7: 388-392.

Skeath, J.B., G. Panganiban, J. Selegue, and S. Carroll. 1992. Gene regulation in two dimensions: The proneural achaete and scute genes are controlled by combinations of axis-patterning genes through a common intergenic control region. Genes \& Dev. 6: 2606-2619.

Sprenger, F. and C. Nüsslein-Volhard. 1992. Torso receptor activity is regulated by a diffusible ligand produced at the extracellular terminal regions of the Drosophila egg. Cell 71: 987-1001.

Steward, R. 1989. Relocalization of the dorsal protein from the cytoplasm to the nucleus correlates with its function. Cell 59: 1179-1188.

Sturtevant, M.A., M. Roark, and E. Bier. 1993. The Drosophila rhomboid gene mediates the localized formation of wing veins and interacts genetically with components of the EGF-R signaling pathway. Genes \& Dev. 7: 961-973.

Tautz, D. and C. Pfeifle. 1989. A non-radioactive in situ hybridization method for the localization of specific RNAs in Drosophila embryos reveals translational control of the segmentation gene hunchback. Chromosoma 98: 81-85.

Thisse, B., C. Stoetzel, M. El Messal, and F. Perrin-Schmitt. 1987. Genes of the Drosophila maternal dorsal group control the specific expression of the zygotic gene twist in the presumptive mesodermal cells. Genes \& Dev. 1: 709-715.

Thisse, C., F. Perrin-Schmitt, C. Stoetzel, and B. Thisse. 1991. Sequence specific transactivation of the Drosophila twist gene by the dorsal gene product. Cell 65: 1191-1201.

van den Heuvel, M., R. Nusse, P. Johnston, and P.A. Lawrence. 1989. Distribution of the wingless gene product in Drosophila embryos: A protein involved in cell-cell communication. Cell 59: 739-749.

Weigel, D., G. Jürgens, F. Küttner, E. Seifert, and H. Jäckle. 1989. The homeotic gene fork head encodes a nuclear protein and is expressed in the terminal regions of the Drosophila embryo. Cell 57: 645-658.

Wharton, K.A., R.P. Ray, and W.M. Gelbart. 1993. An activity gradient of decapentaplegic is necessary for the specification of dorsal pattern elements in the Drosophila embryo. Development 117: 807-822.

Wieschaus, E. and C. Nüsslein-Volhard. 1986. Looking at embryos. In Drosophila, a practical approach (ed. D.B. Roberts), pp. 199-227, IRL press, Oxford, England.

Wieschaus, E., N. Perrimon, and R. Finkelstein. 1992. orthidenticle activity is required for the development of medial structures of the larval and adult epidermis of Drosophila. Development 115: 801-811.

Zak, N.B., R.J. Wides, E.D. Schejter, E. Raz, and B.-Z. Shilo. 1990. Localization of the DER/flb protein in embryos: Implications on the faint little ball lethal phenotype. Development 109: 865-874. 


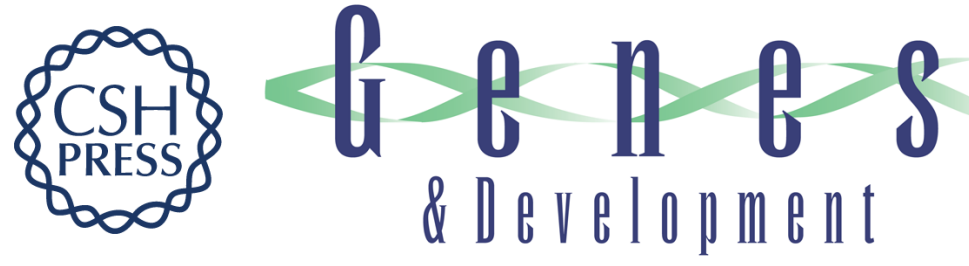

\section{Establishment of ventral cell fates in the Drosophila embryonic ectoderm requires DER, the EGF receptor homolog.}

E Raz and B Z Shilo

Genes Dev. 1993, 7:

Access the most recent version at doi:10.1101/gad.7.10.1937

References This article cites 50 articles, 25 of which can be accessed free at:

http://genesdev.cshlp.org/content/7/10/1937.full.html\#ref-list-1

License

Email Alerting

Service

Receive free email alerts when new articles cite this article - sign up in the box at the top right corner of the article or click here.

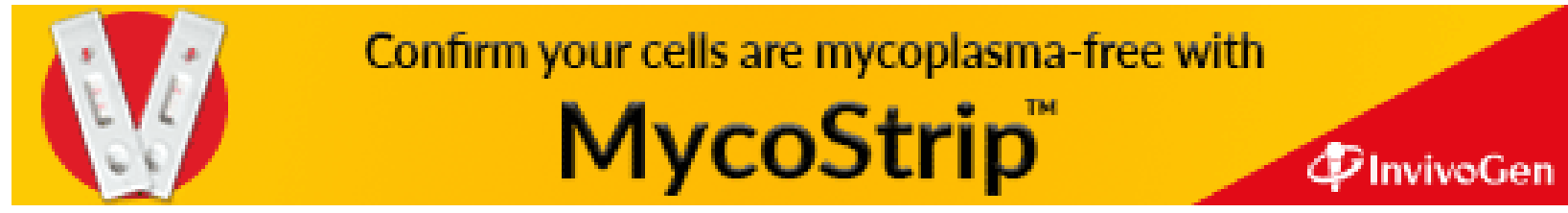

